Z. Mohammadi and M. Field - On the Temporal Behavior of Karst Aquifers, zagros Region, Iran: A Geostatistical Approach. Journal of Cave and Karst Studies, v. 71, no. 3, p. 210-226.

\title{
ON THE TEMPORAL BEHAVIOR OF KARST AQUIFERS, ZAGROS REGION, IRAN: A GEOSTATISTICAL APPROACH
}

\author{
Zargham Mohammadi ${ }^{1}$ And Malcolm Field ${ }^{2}$
}

\begin{abstract}
A geostatistical approach was used to study temporal structures in a time series of discharge and electrical conductivity (EC) in 15 karst springs from the Zagros mountain range, Iran. Two types of temporal behaviors, a periodic structure and nugget effect, plus one or two temporal structures, were identified and interpreted. These correspond to characteristics of karst systems, such as the catchment area, percent of conduit flow, and general degree of karst development. Springs were grouped into three categories based on their ranges (e.g., residence time) obtained by variogram analysis. The first group of springs include those that present the same temporal behaviour in variograms of discharge and EC. These springs are characterized by generally constant EC with increasing discharge suggesting the existence of a large underground reservoir. The second group of springs are those with varying temporal periodic behavior in variograms of discharge and EC. Positive correlation between discharge and $\mathrm{EC}$ values is the main characteristic of these springs and is interpreted to result from a piston-flow system in poorly developed karst aquifers. The third group of springs includes those that exhibit different temporal behaviors when compared with the periodic and non-periodic variograms. This group exhibits a negative correlation in scatterplots of discharge versus EC values suggesting a well-developed solution-conduit system that facilitates rapid response of the karst system to precipitation events. This study's results document the role of variogram analysis in delineating temporal structures of spring behaviors by means of time series of discharge and EC. Variogram analysis can be considered as a valuable tool for hydrogeological investigations in karstic terranes.
\end{abstract}

DOI: $10.4311 /$ jcks2009es 0079

\section{INTRODUCTION}

Karst groundwater is a major water resource in many regions of some countries such as China, Turkey, Iran, the United States, etc. Karstic-carbonate formations cover about $11 \%$ of the land area in Iran $\left(185,000 \mathrm{~km}^{2}\right)$ and $55 \%$ of the Zagros Region (Raeisi, 2004). Carbonate rocks become karstic aquifers by dissolution processes, typically referred to as karstification. Karstification creates a significant heterogeneity of the permeability within the aquifer. Karst development processes and several methods intended to characterize karst systems have been extensively presented in Palmer (2007), Ford and Williams (2007), Bakalowicz (2005), White (1988), Gillieson (1996), Mangin (1994), and Milanović (1981).

The hydrogeological study of karst aquifers is particularly difficult because of the complex and heterogeneous character of the karstic massif and the limited number of available wells that permit hydrogeological observation (Padilla and Pulido-Bosch, 1995; Panagopoulos and Lambrakis, 2006; Mohammadi and Raeisi, 2007). As a result, studies on the function and hydrodynamic behaviour of karst aquifers are focused on the analysis of the characteristics of karst springs. Two commonly measured parameters are discharge and electrical conductivity (EC) that are often presented as a time series. These parameters are widely used by karst researchers because these parameters provide reliable results regarding karst-aquifer characteristics and are relatively easy and inexpensive to collect, especially in less developed area such as the Zagros Region in Iran. Timeseries variations of physico-chemical parameters of springs have been used by many authors for assessing hydrogeochemical aspects of karst aquifers (e.g., Hess and White, 1988; Scanlon and Thraikill, 1987; Raeisi and Karami, 1997; Lopez-Chicano et al., 2001; Desmarais and Rojstaczer, 2002; Karimi et al., 2005a; and Mohammadi et al., 2007). Generally, these authors focused on temporal variations of discharge and chemical parameters caused by a heavy precipitation event in terms of internal and external factors involving the karst system studied. Many authors (e.g., Mangin, 1984; Moore, 1992; Padilla and Pulido-Bosch, 1995; Larocque et al., 1998; Kovacs et al., 2005; and Manga, 1999) applied correlation and spectral analysis on the time series of springs to extract further information about time lag, periodicity, and residence time.

Variogram analyses are extensively used in hydrology (e.g., Bacchi and Kottegoda, 1995; Holawe and Dutter,

Disclaimer: The views expressed in this paper are solely those of the authors and do not necessarily reflect the views or policies of the U.S. Environmental Protection Agency.

${ }^{1}$ Department of Earth Science, Shiraz University, Shiraz, Iran, zmohamad@ shirazu.ac.ir

${ }^{2}$ U.S. Environmental Protection Agency, National Center for Environmental Assessment (8623P), 1200 Pennsylvania, Ave., NW, Washington, DC 20460, USA, field.malcolm@epa.gov 


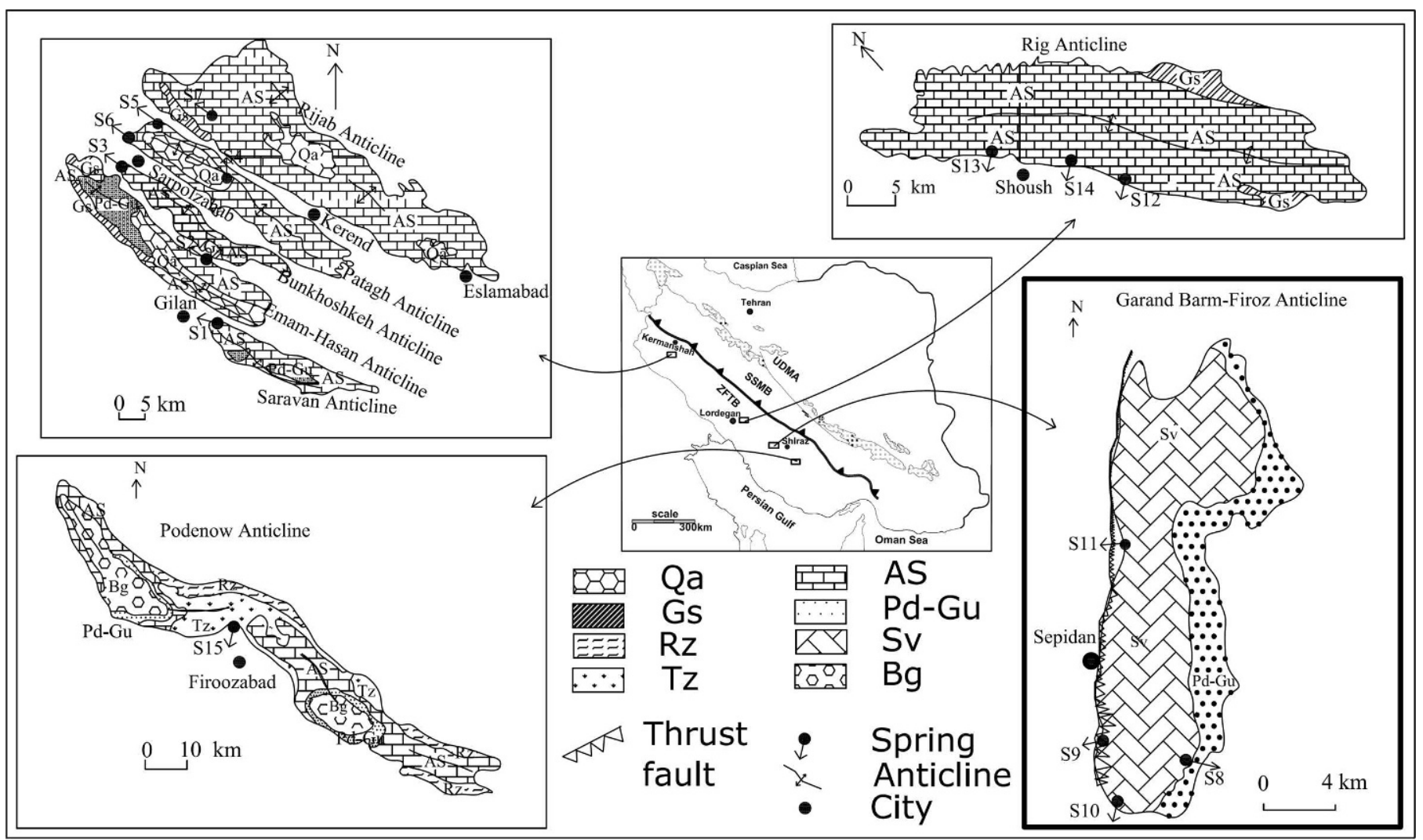

Figure 1. Simplified geological map of the selected aquifers in the Zagros mountain range. See Table 1 for a description of map symbols of depicted geological units.

1999; Berne et al., 2004; Kyriakidis et al., 2004; and Buytaert et al., 2006), but its contribution to a time series of physico-chemical parameters of springs is rare (e.g., Rouhani and Wackernagel, 1990; Goovaerts et al., 1993; Kolovos et al., 2004; and Silliman et al., 2007). Rouhani and Wackernagel (1990) applied variogram analysis to monthly piezometric data at 16 observation wells in a basin south of Paris, France. Two temporal structures were determined by the variogram analysis, including the 12month seasonal and the 12-year climatic cycles. Multivariate geostatistical analysis was applied to spring-watersolute contents measured in 86 springs situated in Belgium by Goovarets et al. (1993).

In this study, we use variogram analyses to evaluate the time-series data of discharge and EC measurements obtained from 15 springs located in the Zagros Region of southern Iran (Fig. 1). The study is aimed at improving our understanding of the temporal dynamics of the karst system in the area. The objectives of this study, with the expectation that a better understanding of karstic aquifers may be obtained, are (1) determination of the temporal structures in the time series of discharge and EC, (2) exploration of new information on the characteristics of the karst systems, and (3) evaluation of the potential of variogram analysis for studying karst development.

\section{Geological and Hydrogeological Settings}

The Zagros Region is located in south-west Iran. The climate is semi-arid in the uplands and arid in the lowlands (south of Iran). Precipitation exhibits large spatial and temporal variability with a mean annual precipitation in the Zagros region of about $450 \mathrm{~mm}$, with a range of 150 to $750 \mathrm{~mm}$. Runoff is an aggregation of several hydrological river basins that discharge to the Persian Gulf. The high elevation areas of the Zagros Region are the zones where the rivers originate; the main rivers flowing in the Zagros region are Karoun River, Dae River, Karkhe River, Hele River, Mond River and Zohre River. Karoun River is the Zagros' most important river with the highest amount of flow and many tributaries in upstream sub-watersheds, the largest of which is the Dez River. Karoun River is a major source of water for 4.5 million inhabitants in the south of Iran (KWPA, 2009).

Iran is geologically a part of the Alpine-Himalayan orogenic belt. The Zagros mountain range extends from the northwest to southeast of Iran and consists of three NW-SE trending parallel zones (Fig. 1): (1) the Urumieh-Dokhtar Magmatic Assemblage (UDMA); (2) the Sanandaj-Sirjan Metamorphic Belt (SSMB); and (3) the Zagros Fold and Thrust Belt (ZFTB). The ZFTB is the study area of this paper. 
Table 1. Stratigraphic column of geological units depicted in Figure 1.

\begin{tabular}{|c|c|c|c|}
\hline Symbol on Figure 1 & Geologic Unit & Geologic Age & Composition \\
\hline $\mathrm{Qa}$ & Recent alluvium & $\ldots$ & $\ldots$ \\
\hline Gs & Gachsaran Formation & Miocene & Gypsum, marl and salt \\
\hline $\mathrm{Rz}$ & Razak Formation & Lower Miocene & $\begin{array}{l}\text { Silty marl to silty limestone with } \\
\text { interbedded layers of gypsum }\end{array}$ \\
\hline $\mathrm{Tz}$ & Transition zone & Lower Miocene & $\begin{array}{l}\text { Transition between Asmari and Razak } \\
\text { Formations }\end{array}$ \\
\hline As & Asmari Formation & Oligocene-Miocene & Limestone, dolomite \\
\hline $\mathrm{Pd}-\mathrm{Gu}$ & Pabdeh-Gurpi Formation & Paleocene-Oligocene & Marl, shale and marly limestone \\
\hline $\mathrm{Sv}$ & Sarvak Formation & Upper Paleocene & Limestone \\
\hline $\mathrm{Bg}$ & Bangestan Group & lower Paleocene & Limestone, shale, marl \\
\hline
\end{tabular}

The stratigraphy and structural framework of the ZFTB were studied in detail by James and Wynd (1965), Stocklin and Setudehnia (1977) and Alavi (2004, 2007). The ZFTB is about $12-\mathrm{km}$ thick and consists mainly of limestone, marl, gypsum, sandstone and conglomerate. Since the Miocene age, it has been folded into a series of huge anticlines and synclines. Most of the carbonate rock outcrops are of Cretaceous and Tertiary age. The most important karst features in the ZFTB are karren, grikes, and springs, and to a lesser extent, caves and sinkholes. Most of the springs are permanent with a high percentage of spring discharge from base flow. The ZFTB is characterized by a repetition of long and regular anticlinal and synclinal folds. The anticlines normally form mountain ridges of limestone and the synclines normally form valleys and plains. Most of the karst formations in the ZFTB are sandwiched between two impermeable formations that form broad highland independent aquifers (Raeisi, 2004; Raeisi and Laumanns, 2003). Several anticlines from different parts of the ZFTB were selected for this study. Simplified geological maps of these anticlines are presented in Figure 1 and a description of the geological units in Table 1.

\section{Several Anticlines in the Alvand River Basin}

The Alvand river basin comprises seven main anticlines (Karimi, 2003), five of which are considered in this study, and include the Saravan, Emam-Hasan, Bunkhoshkeh, Patagh, and Rijab anticlines (Fig. 1). These anticlines are located $\sim 150 \mathrm{~km}$ west of the Kermanshah located in the south-western part of Iran (Fig. 1), follow a northwestsoutheast trend, and are mainly composed of the Asmari limestone. The geologic formations in this area are, from youngest to oldest: 1) recent alluvium; 2) Gachsaran gypsum and marl; 3) Asmari dolomite and limestone; and 4) Pabdeh-Gurpi marl and shale with interbedded, thin marly limestone (Fig. 1). The core of the anticlines is composed of the Asmari formation and is situated between the impermeable upper Gachsaran and lower PabdehGurpi formations (Karimi et al., 2005b). The dense and thick bedded Asmari limestone in the anticlines has numerous joints and fractures with limited solution features and small shelter caves (Karimi et al. 2005b). Generally, the southern flanks are hydraulically disconnected in most parts of the anticlines (Karimi, 2003), except in the plunge areas. Groundwater from the above aquifers discharge from seven main springs including Gilan (S1), Golin (S2), Sarabgarm (S3), Marab (S4), Piran (S5), Gharabolagh (S6) and Rijab (S7) Springs (Fig. 1 and Table 2). There is no hydraulic connection between these springs except the Marab (S4), Piran (S5) and Gharabolagh (S6) which emerge from Patagh Anticline. However, the catchment areas of the springs were mapped without any overlap in their areas (Karimi, 2003).

\section{The Barm-Firooz and Gar Anticlines}

The Barm-Firooz and Gar Anticlines are located $80 \mathrm{~km}$ northwest of Shiraz on a general northwest trend of the Zagros mountain range. The cores of the anticlines are comprised of the calcareous Sarvak formation, which is overlain by impermeable Pabdeh-Gurpi formations (Fig. 1). The most important tectonic feature in this area is a northwest trending thrust fault (Fig. 1). Groundwater from the Sarvak aquifer discharges mainly from Sheshpir (S8), Berghan (S9), Morikosh (S10), and Tangkelagari (S11) Springs (Fig. 1). The most important karst features in the catchment area of Sheshpir Spring (S8) is the presence of 255 sinkholes (Raeisi and Karami, 1997). Several normal faults and one thrust fault have resulted in an extensive brecciated zone in the catchment area of Berghan Spring (S9). No sinkholes or caves are present in the catchment area of Berghan Spring (S9). It seems that karst is developed as a network of interconnected small fissures and pores (Raeisi and Karami, 1997) and with minimal karstification. No hydraulic connection between the catchment area of Sheshpir spring (S8) and three other springs has been reported.

\section{The Rig Anticline}

The Rig anticline is located in Southern Iran near the city of Lordegan. The main formations in this area are the Gachsaran (Miocene), Asmari (Oligocene-Miocene), and 
Table 2. Data sets characteristics used in the analysis.

\begin{tabular}{|c|c|c|c|c|c|}
\hline Spring Name & $\begin{array}{l}\text { Code on } \\
\text { Figure } 1\end{array}$ & Anticline & $\begin{array}{l}\text { Sampling } \\
\text { Interval }\end{array}$ & $\begin{array}{l}\text { Sampling } \\
\text { Period }\end{array}$ & Data Reference \\
\hline Gilan & S1 & Saravan & Weekly $^{\mathrm{a}}$ & 09/'00-09/'01 & Karimi (2003) \\
\hline Golin & S2 & Emam-Hasan & Weekly $^{\mathrm{a}}$ & 09/'00-09/'01 & Karimi (2003) \\
\hline Sarabgarm & S3 & Bunkhoshkeh & Weekly $^{\mathrm{a}}$ & 09/'00-09/'01 & Karimi (2003) \\
\hline Marab & S4 & Patagh & Weekly $^{\mathrm{a}}$ & 09/'00-09/'01 & Karimi (2003) \\
\hline Piran & S5 & Patagh & Weekly $^{\mathrm{a}}$ & 09/'00-09/'01 & Karimi (2003) \\
\hline Gharabolagh & S6 & Patagh & Weekly $^{\mathrm{a}}$ & 09/'00-09/'01 & Karimi (2003) \\
\hline Rijab & S7 & Rijab & Weekly $^{\mathrm{a}}$ & 09/'00-09/'01 & Karimi (2003) \\
\hline Sheshpir & S8 & Gar and Barm-Firoz & Dailyb & 03/'90-11/'91 & $\begin{array}{l}\text { Karami (1993); Pezeshkpoor } \\
\text { (1991) }\end{array}$ \\
\hline Berghan & S9 & Gar and Barm-Firoz & 20 days & 03/'90-11/'91 & $\begin{array}{l}\text { Karami (1993); Pezeshkpoor } \\
\text { (1991) }\end{array}$ \\
\hline Morikosh & S10 & Gar and Barm-Firoz & 20 days & 03/90-11/'91 & $\begin{array}{l}\text { Karami (1993); Pezeshkpoor } \\
\text { (1991) }\end{array}$ \\
\hline Tangkelagari & S11 & Gar and Barm-Firoz & 20 days & 03/'90-11/'91 & $\begin{array}{l}\text { Karami (1993); Pezeshkpoor } \\
\text { (1991) }\end{array}$ \\
\hline Atashgah & S12 & Rig & Weekly $^{\mathrm{a}}$ & 05/'02-09/'03 & Keshavarz (2003) \\
\hline Shosh & S13 & Rig & Weekly $^{\mathrm{a}}$ & 05/'02-09/'03 & Keshavarz (2003) \\
\hline Enakak & S14 & Rig & Weekly $^{\mathrm{a}}$ & 05/'02-09/'03 & Keshavarz (2003) \\
\hline Ghomp & S15 & Podenow & Daily $^{\mathrm{b}}$ & 04/'96-09/'97 & Karimi (1998) \\
\hline
\end{tabular}

${ }^{a}$ One week during rainy season and one or two weeks during dry season.

${ }^{\mathrm{b}}$ Daily during rainy season and two weeks during dry season.

Pbdeh-Gurpi (Paleocene-Oligocene) Formations (Fig. 1). Rig Anticline is a box fold that mainly consists of the karstic Asmari Formation (Keshavarz, 2003). Numerous joint sets are observed in the Asmari Formation. There appears to be no concentrated recharge points, such as sinkholes or sinking streams, in this aquifer. The Atashgah Spring (S12), having a mean discharge rate of about $900 \mathrm{~L} \mathrm{~s}^{-1}$, is the largest spring originating from the Rig Anticline (Fig. 1). Two other large springs, Shosh (S13) and Enakak (S14) Springs, emerge from the Rig anticline (Fig. 1).

\section{The Podenow Anticline}

The Podenow anticline is located south of Shiraz, Iran. The geological formations in decreasing order of age consist of the Bangestan group (lower Palaeocene), Pabdeh-Gurpi (Palaeocene-Oligocene), Asmari (Oligocene-Miocene), Transition zone and Razak (Lower Miocene), as shown in Figure 1. The core of the Podenow anticline is composed of the limestone Asmari Formation which is sandwiched between the two impermeable Pabdeh-Gurpi (marl, shale and marly limestone) and Razak (silty marl to silty limestone with interbedded layers of gypsum) Formations (Fig. 1). This anticline is divided into eastern, central, and western parts based on the orientations of the anticline. The eastern and western sections follow the general northwestern trend of the Zagros mountain range (Karimi et al., 2005a). The largest spring on the southern flank is Ghomp Spring (S15 in Fig. 1).

\section{Materials And Methods}

\section{Data Collection}

Electrical conductivity and discharge measurements from the 15 springs from the Zagros mountain range were used for this study. Sampling intervals and sampling periods for each spring are presented in Table 2. Electrical conductivity was measured by a portable ELE EC-meter in the field immediately after sampling. Spring discharge was measured by current-meter or triangular weir related to spring discharge and field conditions. Hydrogeological characteristics of the studied springs are presented in Table 3 .

\section{Data Analysis}

Exploratory data analysis and variogram analysis were used for database analyses. Use of multiple data analyses techniques provides greater insight into the information contained in a database (Farnham et al., 2000; Silliman et al., 2007).

\section{Exploratory-Data Analysis}

Exploratory data analysis is a purely descriptive part of the study that allows for a good preliminary assessment of the collected data (Isaaks and Srivastava, 1989). There is no single statistical tool as powerful as a plot of the data (Chambers et al., 1983). The distribution of continuous variables can be depicted by a histogram with the range of data values discretized into a specific number of classes of equal width and the relative proportion of data within each

Journal of Cave and Karst Studies, December 2009•213 
Table 3. Hydrogeological characteristics of the studied springs.

\begin{tabular}{|c|c|c|c|c|c|c|}
\hline Spring Name & Elevation (m) & $\begin{array}{l}\text { Watershed } \\
\text { Area }\left(\mathrm{km}^{2}\right)\end{array}$ & $\begin{array}{l}\text { Annual } \\
\text { Precipitation } \\
(\mathrm{mm})\end{array}$ & $\begin{array}{l}\text { Percent of } \\
\text { Conduit } \\
\text { Flow }\end{array}$ & $\begin{array}{c}\text { Ratio of } \\
\text { Recession Coeff. } \\
\left(a_{1} / a_{2}\right)\end{array}$ & $\begin{array}{l}\text { Ratio of Max. to } \\
\text { Min. Discharges } \\
\left(Q_{\max } / Q_{\min }\right)\end{array}$ \\
\hline Gilan & 1413 & 110 & 473 & 8 & 0.57 & 1.58 \\
\hline Golin & 1526 & 68.8 & 492 & 3.7 & 1 & 1.12 \\
\hline Sarabgarm & 1191 & 204.1 & 454 & 5.4 & 75 & 1.35 \\
\hline Marab & 1879 & 42 & 515 & 35 & 26.7 & 5.25 \\
\hline Piran & 1176 & 26.7 & 460 & 15 & 1 & 1.39 \\
\hline Gharabolagh & 1576 & 56.8 & 515 & 6.9 & 4.5 & 1.36 \\
\hline Rijab & 1874 & 221 & 552 & 35 & 3.08 & 7.58 \\
\hline Sheshpir & 2335 & 81 & 1334 & 24 & 11.5 & 4.56 \\
\hline Berghan & 2145 & 19 & 798 & 23.7 & 2 & 3.92 \\
\hline Morikosh & 2450 & 4.3 & 1122 & 31 & 2.7 & 15.5 \\
\hline Tangkelagari & 2120 & 4.47 & 985 & 28 & 2.5 & 15.2 \\
\hline Atashgah & 1710 & 62 & 930 & 13.5 & 4.4 & 1.91 \\
\hline Shosh & 1500 & 18.2 & 910 & 21 & 2 & 5.69 \\
\hline Enakak & 1750 & 5 & 890 & 25 & 2.2 & 7.6 \\
\hline Ghomp & 1350 & 114.2 & 400.7 & 29.5 & 4.4 & 3.03 \\
\hline
\end{tabular}

class (e.g., frequency) by the height of bars (Goovaerts, 1997). Important features of a distribution are its central tendency and measure of its spread and symmetry. The relationship between pairs of variables can be depicted in a scatterplot, which is the simplest and probably most informative method for comparing data pairs (Deutsch and Journel, 1992). The correlation coefficient is mostly used as a measure of bivariate relationships. Here, exploratory data analyses include histograms and probability plots of the discharge and EC data series for each spring and relationships among pairs of discharge and EC data as scatterplots. The data plots were developed using Statistica Software, Release 6 (StatSoft, 2001).

\section{Variogram Analysis}

The variogram approach is extensively used in geological and environmental sciences to assess the characteristics of spatially or temporarily distributed data (e.g., Isaaks and Srivastava, 1989; Goovaerts, 1997; Webster and Oliver, 2001). The variogram measures the spatial and/or temporal behavior of a variable of interest (Deutsch and Journel, 1992). It is easy to interpret the time axis as the location coordinate in the variogram analysis (Holawe and Dutter, 1999). Many papers in various disciplines have been published using variogram methods for different regionalized variables at different time scales of interest (e.g., Holawe and Dutter, 1999; Berne et al., 2004; Buytaert et al., 2006). Variogram modeling and analysis was accomplished using the program, VESPAR (Minasny et al., 2005).

Assuming the studied time series of observations is a realization of a random function $Z$, so that $z(t), t=$ $1,2,3, \ldots, m$, where $z(t)$ refers to observed values of discharge or EC at time $t$ and $m$ is the length of sampling period. Given two times, $t$ and $t+h$ inside the period of temporal attribute $z(t)$, the experimental variogram is a measure of one half the mean square error produced by assigning the value $z(t+h)$ to the value $z(t)$, as follow:

$$
\gamma(h)=\frac{1}{2 N(h)} \sum_{i=1}^{N(h)}[z(t+h)-z(t)]^{2}
$$

where $N(h)$ is the number of pairs of observations for a time separation, $h$. The shape of semivariograms is quantified by the behavior of the variogram at the origin (nugget effect), range, and sill.

The nugget effect is a measure of the variability of a variable within small time lengths. Normally the nugget effect is seen as a consequence of the limited number of observations with arbitrarily small time periods (Holawe and Dutter, 1999). Smaller nugget values translate into higher values of influence of small time lags. Therefore, nugget values can be interpreted as altering variables that can play a special role in a simulation model (Holawe and Dutter, 1999). The range, in the case of time dependence, is a measure related to the length of influence of a variable (Holawe and Dutter, 1999). The sill is a value of the covariance that becomes zero when the variogram reaches a constant value. This total sill is equal to the basic variance of the variable. Therefore, the sill is an indicator for the variance in the data field and, in the case of a time series, a measure of the temporal variability.

In order to describe the variogram structure, it is necessary to fit a model to the experimental variogram. The permissible models are presented by Isaaks and Srivastava (1989). The goodness of fit of different models can be 

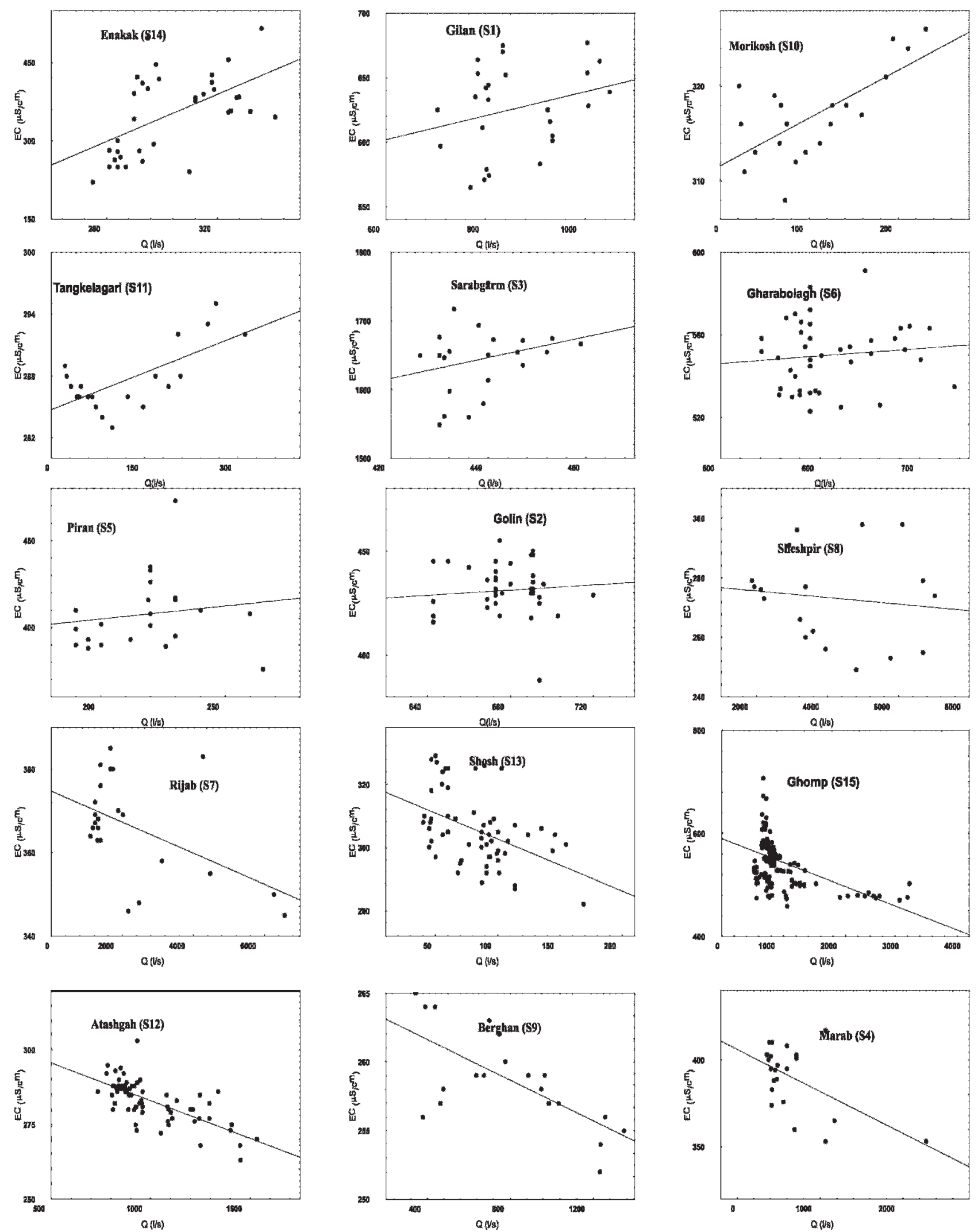

Figure 2. Scatterplots of discharge and EC values for springs. 
Table 4. Descriptive statistics of discharge and electrical conductivity for studied springs.

\begin{tabular}{|c|c|c|c|c|c|c|c|c|c|}
\hline Spring & $\begin{array}{l}\text { Number } \\
\text { of Samples }\end{array}$ & Mean & Median & Minimum & Maximum & Range & $\begin{array}{l}\text { Std. } \\
\text { Dev. }\end{array}$ & Skewness & $\begin{array}{c}\text { C.V } \\
\%\end{array}$ \\
\hline \multicolumn{10}{|l|}{ Gilan } \\
\hline Discharge $\left(\mathrm{L} \mathrm{s}^{-1}\right)$ & 40 & 861.1 & 820.5 & 704 & 1050 & 346 & 99.9 & 0.5 & 11.6 \\
\hline Elec. Cond. $\left(\mu \mathrm{cm}^{-1}\right)$ & 40 & 626.2 & 630.5 & 565 & 677 & 112 & 33.8 & -0.3 & 5.4 \\
\hline \multicolumn{10}{|l|}{ Golin } \\
\hline Discharge $\left(\mathrm{L} \mathrm{s}^{-1}\right)$ & 42 & 675.4 & 674 & 643 & 720 & 77 & 19.1 & -0.3 & 2.8 \\
\hline Elec. Cond. $\left(\mu \mathrm{cm}^{-1}\right)$ & 42 & 431.0 & 430.5 & 388 & 455 & 67 & 12.2 & -0.8 & 2.8 \\
\hline \multicolumn{10}{|l|}{ Sarabgarm } \\
\hline Discharge $\left(\mathrm{L} \mathrm{s}^{-1}\right)$ & 41 & 438.8 & 438.5 & 426 & 459 & 33 & 8.8 & 0.7 & 2.0 \\
\hline Elec. Cond. $\left(\mu \mathrm{cm}^{-1}\right)$ & 41 & 1644.8 & 1653 & 1549 & 1755 & 206 & 51.0 & -0.2 & 3.1 \\
\hline \multicolumn{10}{|l|}{ Marab } \\
\hline Discharge $\left(\mathrm{L} \mathrm{s}^{-1}\right)$ & 42 & 646.9 & 481 & 354 & 2276 & 1922 & 427.1 & 2.8 & 66.0 \\
\hline Elec. Cond. $\left(\mu \mathrm{cm}^{-1}\right)$ & 42 & 390.4 & 395 & 353 & 417 & 64 & 18.6 & -0.8 & 4.8 \\
\hline \multicolumn{10}{|l|}{ Piran } \\
\hline Discharge $\left(\mathrm{L} \mathrm{s}^{-1}\right)$ & 40 & 218.3 & 220 & 190 & 265 & 75 & 20.9 & 0.5 & 9.6 \\
\hline Elec. Cond. $\left(\mu \mathrm{cm}^{-1}\right)$ & 40 & 407.6 & 405 & 376 & 473 & 97 & 21.1 & 1.4 & 5.2 \\
\hline \multicolumn{10}{|l|}{ Gharabolagh } \\
\hline Discharge $\left(\mathrm{L} \mathrm{s}^{-1}\right)$ & 42 & 609.8 & 590 & 541 & 735 & 194 & 48.5 & 0.9 & 8.0 \\
\hline Elec. Cond. $\left(\mu \mathrm{cm}^{-1}\right)$ & 42 & 550.1 & 551.5 & 523 & 591 & 68 & 15.9 & 0.3 & 2.9 \\
\hline \multicolumn{10}{|l|}{ Rijab } \\
\hline Discharge $\left(\mathrm{L} \mathrm{s}^{-1}\right)$ & 42 & 2275.0 & 1670 & 1096 & 6560 & 5464 & 1597.5 & 1.8 & 70.2 \\
\hline Elec. Cond. $\left(\mu \mathrm{cm}^{-1}\right)$ & 42 & 366.3 & 367 & 345 & 385 & 40 & 11.8 & -0.3 & 3.2 \\
\hline \multicolumn{10}{|l|}{ Sheshpeer } \\
\hline Discharge $\left(\mathrm{L} \mathrm{s}^{-1}\right)$ & 201 & 4004.3 & 3744.2 & 1493.3 & 7191.5 & 5698.2 & 1351.4 & 0.5 & 33.7 \\
\hline Elec. Cond. $\left(\mu \mathrm{cm}^{-1}\right)$ & 18 & 273.3 & 275 & 249 & 298 & 49 & 15.6 & 0.2 & 5.7 \\
\hline \multicolumn{10}{|l|}{ Berghan } \\
\hline Discharge $\left(\mathrm{L} \mathrm{s}^{-1}\right)$ & 20 & 796.3 & 762.5 & 345 & 1348 & 1003 & 323.7 & 0.2 & 40.6 \\
\hline Elec. Cond. $\left(\mu \mathrm{cm}^{-1}\right)$ & 20 & 258.7 & 258.5 & 252 & 265 & 13 & 3.5 & 0.2 & 1.4 \\
\hline \multicolumn{10}{|l|}{ Morikosh } \\
\hline Discharge $\left(\mathrm{L} \mathrm{s}^{-1}\right)$ & 20 & 106.0 & 90.5 & 21 & 231 & 210 & 64.1 & 0.5 & 60.5 \\
\hline Elec. Cond. $\left(\mu \mathrm{cm}^{-1}\right)$ & 20 & 317.0 & 316.5 & 308 & 326 & 18 & 4.7 & 0.3 & 1.5 \\
\hline \multicolumn{10}{|l|}{ Tangkelagari } \\
\hline Discharge $\left(\mathrm{L} \mathrm{s}^{-1}\right)$ & 21 & 119.0 & 82 & 22 & 311 & 289 & 88.8 & 0.8 & 74.6 \\
\hline Elec. Cond. $\left(\mu \mathrm{cm}^{-1}\right)$ & 21 & 287.6 & 287 & 283 & 295 & 12 & 3.1 & 1.0 & 1.1 \\
\hline \multicolumn{10}{|l|}{ Atashgah } \\
\hline Discharge $\left(\mathrm{L} \mathrm{s}^{-1}\right)$ & 67 & 998.7 & 926.61 & 733 & 1533 & 800 & 194.7 & 1.1 & 19.5 \\
\hline Elec. Cond. $\left(\mu \mathrm{cm}^{-1}\right)$ & 67 & 283.0 & 285 & 263 & 303 & 40 & 7.1 & -0.3 & 2.5 \\
\hline \multicolumn{10}{|l|}{ Shosh } \\
\hline Discharge $\left(\mathrm{L} \mathrm{s}^{-1}\right)$ & 61 & 82.6 & 87 & 40 & 169 & 129 & 30.4 & 0.7 & 36.8 \\
\hline Elec. Cond. $\left(\mu \mathrm{cm}^{-1}\right)$ & 61 & 305.5 & 304 & 282 & 329 & 47 & 11.2 & 0.5 & 3.7 \\
\hline \multicolumn{10}{|l|}{ Enakak } \\
\hline Discharge $\left(\mathrm{L} \mathrm{s}^{-1}\right)$ & 35 & 303.4 & 297 & 275 & 341 & 66 & 18.6 & 0.4 & 6.1 \\
\hline Elec. Cond. $\left(\mu \mathrm{cm}^{-1}\right)$ & 35 & 351.3 & 357 & 221 & 515 & 294 & 77.8 & 0.1 & 22.2 \\
\hline \multicolumn{10}{|l|}{ Ghomp } \\
\hline Discharge $\left(\mathrm{L} \mathrm{s}^{-1}\right)$ & 218 & 887.3 & 771 & 527 & 3031 & 2504 & 418.9 & 3.4 & 47.2 \\
\hline Elec. Cond. $\left(\mu \mathrm{cm}^{-1}\right)$ & 218 & 548.2 & 553 & 458 & 707 & 249 & 39.1 & 0.2 & 7.1 \\
\hline
\end{tabular}



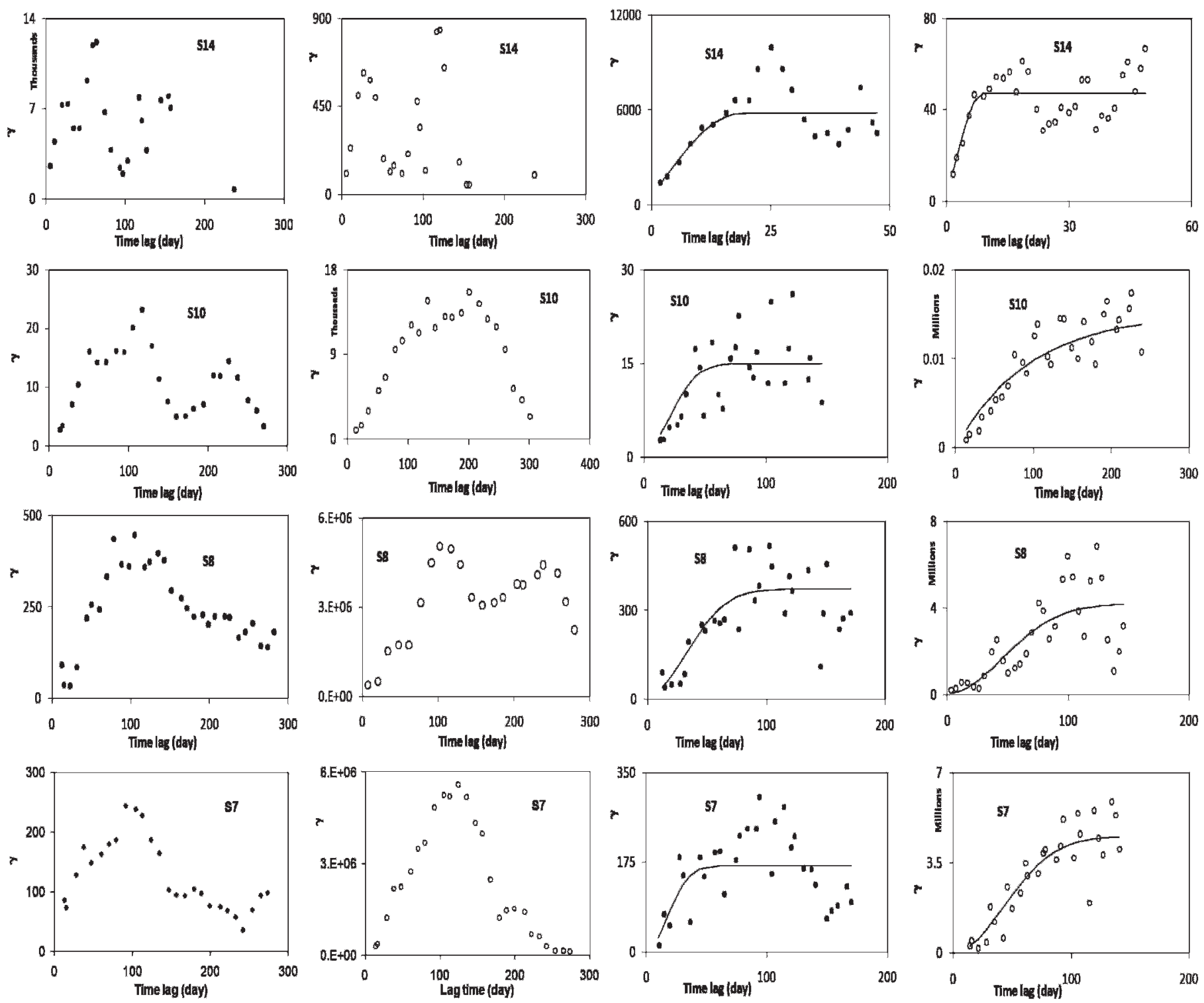

Figure 3. Variograms before (panel 1 and 2 from left) and after removing periodic behavior (panel 3 and 4 from left); solid circles $=\mathrm{EC}$; open circles $=$ discharge.

assumed using the Root Mean Square Error (RMSE), Akaike Information Criteria (AIC) and weighted Sum of Square Error (SSE).

\section{RESULTS}

The scatterplots of discharge versus EC and their distributions are shown in Figure 2. Most of the histograms were positively skewed, indicating the presence of large data values for both discharge and EC occurred with low frequency. All histograms were fitted to a lognormal distribution. The descriptive statistics of discharge and EC values for the springs are shown in Table 4.
The correlation among the discharge and EC variables for each spring is shown in Figure 2. Discharge and EC values are positively correlated in Gilan (S1), Sarabgarm (S3), Morikosh (S10), Tangkelagari (S11), and Enakak (S14) Springs, but only partly in Golin (S2), Piran (S5), and Gharabolagh (S6) Springs (Fig. 2). Negative correlation between discharge and EC values is evident for Marab (S4), Rijab (S7), Berghan (S9), Atashgah (S12), Shosh (S13), Ghomp (S15) Springs, but less so in Sheshpir Spring (S8). The strong negative correlation between discharge and EC may be interpreted as an indication of a freshwater recharge signal during the rainy season, which yields a considerable volume of low-EC water. The somewhat constant EC versus discharge values for Piran (S5) and 
Table 5. The value of fitting criteria in modeling of periodic variograms after removing the periodicity (the best models are presented by bold numbers).

\begin{tabular}{|c|c|c|c|c|}
\hline \multirow[b]{2}{*}{ Spring } & \multirow[b]{2}{*}{ Fitting Criteria } & \multicolumn{3}{|c|}{ Model } \\
\hline & & Exp. & Gau. & Sph. \\
\hline \multicolumn{5}{|l|}{ Sarabgarm } \\
\hline \multirow[t]{3}{*}{ Discharge } & RMSE & 23.8 & 25 & 22.7 \\
\hline & AIC & 287 & 190 & 285 \\
\hline & SSE & 17 & 10 & 11 \\
\hline \multirow[t]{3}{*}{ Elec. Cond. } & RMSE & 703 & 727 & 723 \\
\hline & AIC & 484 & 486 & 485 \\
\hline & SSE & 703 & 727 & 723 \\
\hline \multicolumn{5}{|l|}{ Marab } \\
\hline \multirow[t]{3}{*}{ Discharge } & RMSE & 139,988 & 138,152 & 139,014 \\
\hline & $\mathrm{AIC}$ & 791 & 790 & 790 \\
\hline & SSE & 391 & 352 & 446 \\
\hline \multirow[t]{3}{*}{ Elec. Cond. } & RMSE & 127 & 128 & 127 \\
\hline & AIC & 384 & 385 & 384 \\
\hline & SSE & 20 & 21 & 20 \\
\hline \multicolumn{5}{|l|}{ Rijab } \\
\hline \multirow[t]{3}{*}{ Discharge } & RMSE & 930,689 & 784,578 & 854,776 \\
\hline & $\mathrm{AIC}$ & 869 & 859 & 864 \\
\hline & SSE & 172 & 31 & 102 \\
\hline \multirow{3}{*}{ Elec. Cond. } & RMSE & 64 & 61 & 61 \\
\hline & $\mathrm{AIC}$ & 345 & 342 & 342 \\
\hline & SSE & 125 & 86 & 124 \\
\hline \multicolumn{5}{|l|}{ Sheshpeer } \\
\hline \multirow[t]{3}{*}{ Discharge } & RMSE & $1,411,274$ & $1,267,446$ & $1,345,383$ \\
\hline & $\mathrm{AIC}$ & 990 & 983 & 987 \\
\hline & SSE & 760 & 246 & 362 \\
\hline \multirow[t]{3}{*}{ Elec. Cond. } & RMSE & 102 & 92 & 93 \\
\hline & $\mathrm{AIC}$ & 359 & 353 & 353 \\
\hline & SSE & 113 & 83 & 85 \\
\hline \multicolumn{5}{|l|}{ Morikosh } \\
\hline \multirow[t]{3}{*}{ Discharge } & RMSE & 1252 & 1033 & 1167 \\
\hline & $\mathrm{AIC}$ & 517 & 506 & 513 \\
\hline & SSE & 219 & 35 & 152 \\
\hline \multirow[t]{3}{*}{ Elec. Cond. } & RMSE & 11 & 10 & 10.8 \\
\hline & $\mathrm{AIC}$ & 190 & 186 & 187 \\
\hline & SSE & 25 & 20 & 21.6 \\
\hline \multicolumn{5}{|l|}{ Tangkelagari } \\
\hline \multirow[t]{3}{*}{ Discharge } & RMSE & 2083 & 2011 & 2008 \\
\hline & AIC & 247 & 545 & 544 \\
\hline & SSE & 38 & 11 & 19.4 \\
\hline \multirow[t]{3}{*}{ Elec. Cond. } & RMSE & 4.7 & 4.6 & 4.6 \\
\hline & AIC & 172 & 170 & 170 \\
\hline & SSE & 31 & 29 & 36 \\
\hline \multicolumn{5}{|l|}{ Shosh } \\
\hline \multirow[t]{3}{*}{ Discharge } & RMSE & 267 & 250 & 251 \\
\hline & AIC & 459 & 455 & 455 \\
\hline & SSE & 53 & 43 & 55 \\
\hline
\end{tabular}


Table 5. Continued.

\begin{tabular}{|c|c|c|c|c|}
\hline \multirow[b]{2}{*}{ Spring } & \multirow[b]{2}{*}{ Fitting Criteria } & \multicolumn{3}{|c|}{ Model } \\
\hline & & Exp. & Gau. & Sph. \\
\hline \multirow[t]{3}{*}{ Elec. Cond. } & RMSE & 9.6 & 9.6 & 9.2 \\
\hline & AIC & 252 & 253 & 250 \\
\hline & SSE & 41 & 40 & 32 \\
\hline \multicolumn{5}{|l|}{ Enakak } \\
\hline \multirow{3}{*}{ Discharge } & RMSE & 106 & 79 & 9.2 \\
\hline & AIC & 266 & 253 & 250 \\
\hline & SSE & 50 & 26 & 32 \\
\hline \multirow[t]{3}{*}{ Elec. Cond. } & RMSE & 1644 & 1550 & 1548 \\
\hline & AIC & 381 & 378 & 378 \\
\hline & SSE & 41 & 37 & 37 \\
\hline \multicolumn{5}{|l|}{ Ghomp } \\
\hline \multirow[t]{3}{*}{ Discharge } & RMSE & 640 & 377 & 569 \\
\hline & AIC & 427 & 399 & 423 \\
\hline & SSE & 38 & 13 & 33 \\
\hline \multirow[t]{3}{*}{ Elec. Cond. } & RMSE & 87 & 91 & 79 \\
\hline & AIC & 389 & 392 & 384 \\
\hline & SSE & 16 & 26 & 16.8 \\
\hline
\end{tabular}

Sheshpir (S8) Springs could be caused by (1) a large underground lake that supplies most of the spring discharge water, but also has the capability of damping EC values, or (2) a small or non-rapid recharge component. Alternatively, the generally positive correlation between discharge and EC values may suggest a piston-flow regime in a less developed karst aquifer, which forces water from temporary detention out into a solution conduit for transit to spring outlets during high-flow periods as a result of rising head in the aquifer. In addition, higher mineralized water may be stored in the epikarst, which may contain soluble formations.

\section{VAriogram Temporal Structures}

The experimental variograms were computed for discharge- and EC-time series data for all springs. Temporal behaviors of springs in terms of variograms is different for discharge- and EC-time series. Two temporal structures are evident in variograms: (1) a periodic behavior and (2) a nugget effect with one or two scales of temporal structures.

\section{Periodicity}

Several variograms seem to fluctuate periodically so it is necessary to describe them with a periodic function. One usually observes a variety of temporal periodicities, such as periodic seasonal or annual cycles. The simplest such function is a sine wave (Webster and Oliver, 2001)

$$
\begin{aligned}
\gamma(h) & =C_{1} \operatorname{Cos} \theta+C_{2} \operatorname{Sin} \theta \\
C_{1} & =W \operatorname{Cos} \phi \\
C_{2} & =W \operatorname{Sin} \phi \\
\theta & =\frac{2 \pi h}{\omega}
\end{aligned}
$$

where $W, \omega$ and $\phi$ are the amplitude, length of wave, and phase shift, respectively. The variograms of the discharge and EC values indicate two cyclical trends (Fig. 3). The relative impacts of these cycles may vary from spring to spring, as well as from discharge to EC values. For example, Figure 3 clearly illustrates that the Rijab (S7), Morikosh (S10), and Tangkelagari (S11) Springs have much stronger seasonal components (i.e., effects) than do the Sarabgarm (S3), Sheshpir (S8) and Ghomp (S15) Springs. Discharge variograms display a periodic structure in the Sarabgarm (S3), Rijab (S7), Morikosh (S10), Tangkelagari (S11), and Shosh (S13) Springs while the Marab (S4), Rijab (S7), Sheshpir (S8), Morikosh(S10), and Tangkelagai (S11) Springs reflect periodic processes in EC variograms. Variograms for discharge and EC depict periodicity wavelengths for the springs that range from less than 100 days for Enakak Spring (S14) to more than 316 days for Sarabgarm Spring (S3) and from 82 days in Enakak Spring (S14) to more than 300 days in Sheshpir Spring (S8). These differences may be a result of the catchment areas of the springs. Smaller variogram wavelengths were observed for springs characterized by smaller size of catchment area

Journal of Cave and Karst Studies, December 2009•219 
because of the small distance between the outlet and the hindmost point in the catchment area.

To remove the periodicity and explore the short temporal structures, we use a partial series of discharge and EC values for the springs. These partial series include measured discharge and EC values during a single cyclical period, only. The variograms of these partial time series are shown in Figure 3, and the performance of the different simulation models for temporal behavior of the variograms are presented in Table 5. The variogram parameters (i.e., nugget effect, range(s), and sill(s)) are listed in Table 6 based on the selected best models. The range (A1 in Table 6) varies from 10 days for Shosh Spring (S13) to 114 days for Marab Spring (S4) and from 9 days for Enakak Spring (S14) to 107 days for Sarabgarm Spring (S3), according to variograms of discharge and EC values, respectively. The range depicts a time length (i.e., discharge and/or EC) with minimum correlation. Therefore, it seems that the contribution of a flow component (e.g., conduit(s) or matrix porosity) gradually increases during the range time scale (A1) and its effect disappears in spring water.

\section{Nugget Effect and Temporal Structures}

Several of the variograms have a small nugget effect and show one or two scales of temporal structures (Fig. 4). The performance of permissible models are evaluated based on performance indexes (Table 7). The best model for simulating temporal behaviors of experimental variograms are then selected (Table 6). The nugget effect is well pronounced for Golin Spring (S2), Piran Spring (S5), and Gharabolagh (S6) Spring (Fig. 4), and this behavior may be caused by (1) measurement error and/or (2) microvariability (e.g., variability at a scale smaller than the sampling resolution (Kitanidis, 1997)).

Two ranges with different time scales were obtained during the modeling procedure. One and two temporal structures are observed for Gilan Spring (S1), Golin Spring (S2), Berghan Spring (S9), and Tangkelagari Spring (S11), and for Atashgah Spring (S12) and Sheshpir Spring (S8), respectively (Fig. 4). The different temporal behaviors (i.e., the shape of variograms) are likely caused by different karst systems or subsystems within the aquifers.

Short range variations $\left(\mathrm{A}_{1}\right)$ occur from 17 days at Berghan Spring (S9) to 268 days at Atashgah Spring (S12) and from 28 days at Berghan Spring (S9) to 110 days at Atashgah Spring (S12) for variograms of discharge and EC, respectively. Range $A_{1}$ could be evaluated as an indicator of the length of time that spring water is dominantly supplied by a part of the karst system that contains well-developed solution conduits. The short range length of time is proposed as a measure of residence time for water stored in large solution conduits as being more important for water movement than for water storage. Long range time values (A2) are estimated to exceed 220 days (Table 6). It would seem that the entire karst system is responsive to $A_{2}$. Range $A_{2}$ may be regarded as a measure of water residence time in the fissured matrix. Temporal values of discharge and EC are uncorrelated after the $\mathrm{A}_{2}$ time period, suggesting that the contribution of the entire karst system diminishes after this time period. The results of previous studies on residence time of some springs (Karimi, 2003) confirm our findings.

\section{Discussion}

Variations in discharge and EC in the studied springs is complex and exhibit varying temporal behaviors. The exploratory data analysis presents the information in a compact format as the first step for determining temporal structure. Plots of the obtained range (A1) according to variogram analysis versus catchment areas, percent of discharge quick flow $(\% Q)$, and ratio of maximum discharge to minimum discharge $\left(Q_{\max } / Q_{\min }\right)$ are presented in Figure 5. From Figure 5, it is apparent that springs with small catchment areas have shorter ranges (i.e., residence time) than those springs with larger catchment areas. The higher values of range (A1) are observed in springs that are characterized by lower percentages of quick flow, as well as the ratio of maximum discharge to minimum discharge $\left(Q_{\max } / Q_{\text {min }}\right)$ (Fig. 5).

The discharge and EC variograms provide different ranges (i.e., residence time) for each spring. Differences between the ranges might be a result of influence of the behavior of the karst system that supplies spring water. Differences between the two ranges obtained, based on variograms of discharge and EC for the springs, vary from seven days in Piran Spring (S5) to 158 days in Atashgah Spring (S12) (Table 8). The springs could be classified into three groups based on the percent of difference between the ranges (Table 8): Group 1 springs are those springs with less than $40 \%$ differences; Group 2 are those springs with 40 to $70 \%$ differences; and Group 3 are those springs with greater than 70\% differences. Group 1 includes Golin (S2), Piran (S5), Gharabolagh (S6), Sheshpir (S8) and Berghan (S9) Springs that are characterized by (1) no obvious trend in scatterplots of discharge versus EC values (Fig. 2); and (2) same temporal behavior of variograms of discharge and EC values (Figs. 3 and 4). It would seem that for these springs, spring water may be supported by a large underground karst reservoir. Heavy precipitation events could be damped by this underground reservoir. Accordingly, the temporal behavior of discharge and EC are controlled by the underground reservoir because large precipitation events do not translate into significant discharge increases and EC fluctuations (i.e., sharp increase followed by a significant decrease below the static condition). Small differences between the ranges suggest the possibility of large karst openings that supply spring water. The existence of an underground karst reservoir (or huge solutional conduits) supplying water to Sheshpir Spring (S8) was reported by Raeisi and Karami (1997). 
Table 6. Parameters of selected variograms.

\begin{tabular}{|c|c|c|c|c|c|c|}
\hline Spring & Model & $\mathrm{C}_{0}{ }^{\mathrm{a}}$ & $\mathrm{C}_{1}{ }^{\mathrm{b}}$ & $\mathrm{A}_{1}^{\mathrm{c}}$ & $\mathrm{C}_{2}{ }^{\mathrm{b}}$ & $\mathrm{A}_{2}{ }^{\mathrm{c}}$ \\
\hline \multicolumn{7}{|l|}{ Gilan } \\
\hline Discharge & Gau. & 2138 & 14381 & 108 & & \\
\hline Elec. Cond. & Gau. & 172 & 1414 & 70 & & \\
\hline \multicolumn{7}{|l|}{ Golin } \\
\hline Discharge & Gau. & 343 & 432 & 98 & & \\
\hline Elec. Cond. & Gau. & 103 & 92 & 126 & & \\
\hline \multicolumn{7}{|l|}{ Sarabgarm } \\
\hline Discharge & Sph. & 29 & 75 & 107 & & \\
\hline Elec. Cond. & Exp. & 954 & 2114 & 69 & & \\
\hline \multicolumn{7}{|l|}{ Marab } \\
\hline Discharge & Gau. & 28053 & 254974 & 46 & & \\
\hline Elec. Cond. & Sph. & 58 & 482 & 114 & & \\
\hline \multicolumn{7}{|l|}{ Piran } \\
\hline Discharge & 2 Exp. & 134 & 133 & 88 & 545 & 224 \\
\hline Elec. Cond. & Gau. & 208 & 398 & 95 & & \\
\hline \multicolumn{7}{|l|}{ Gharabolagh } \\
\hline Discharge & Sph. & 146 & 122 & 51 & & \\
\hline Elec. Cond. & Gau. & 383 & 3058 & 41 & & \\
\hline \multicolumn{7}{|l|}{ Rijab } \\
\hline Discharge & Gau. & 50000 & 4458351 & 61 & & \\
\hline Elec. Cond. & Gau. & 0 & 167 & 95 & & \\
\hline \multicolumn{7}{|l|}{ Sheshpeer } \\
\hline Discharge & Gau. & 82207 & 4103478 & 65 & & \\
\hline Elec. Cond. & Gau. & 16.5 & 355 & 47 & & \\
\hline \multicolumn{7}{|l|}{ Berghan } \\
\hline Discharge & 2 Exp. & 0 & 48541 & 28 & 303380 & 272 \\
\hline Elec. Cond. & $2 \mathrm{Sph}$. & 0 & 0.3 & 17 & 27 & 269 \\
\hline \multicolumn{7}{|l|}{ Morikosh } \\
\hline Discharge & Exp. & 0 & 15041 & 94 & & \\
\hline Elec. Cond. & Gau. & 1.2 & 14 & 31 & & \\
\hline \multicolumn{7}{|l|}{ Tangkelagari } \\
\hline Discharge & Gau. & 56 & 6021 & 60 & & \\
\hline Elec. Cond. & Gau. & 1.5 & 24 & 33 & & \\
\hline \multicolumn{7}{|l|}{ Atashgah } \\
\hline Discharge & Sph. & 2209 & 50000 & 110 & & \\
\hline Elec. Cond. & Sph. & 1.7 & 19.5 & 268 & & \\
\hline \multicolumn{7}{|l|}{ Shosh } \\
\hline Discharge & Gau. & 420 & 874 & 39 & & \\
\hline Elec. Cond. & Sph. & 0 & 47 & 10 & & \\
\hline \multicolumn{7}{|l|}{ Enakak } \\
\hline Discharge & Sph. & 0 & 47 & 9 & & \\
\hline Elec. Cond. & Sph. & 480 & 5353 & 19 & & \\
\hline \multicolumn{7}{|l|}{ Ghomp } \\
\hline Discharge & Gau. & 484 & 6636 & 26 & & \\
\hline Elec. Cond. & Sph. & 193 & 750 & 54 & & \\
\hline
\end{tabular}


ON THE TEMPORAL BEHAVIOR OF KARST AQUIFERS, ZAGROS REGION, IRAN: A GEOSTATISTICAL APPROACH
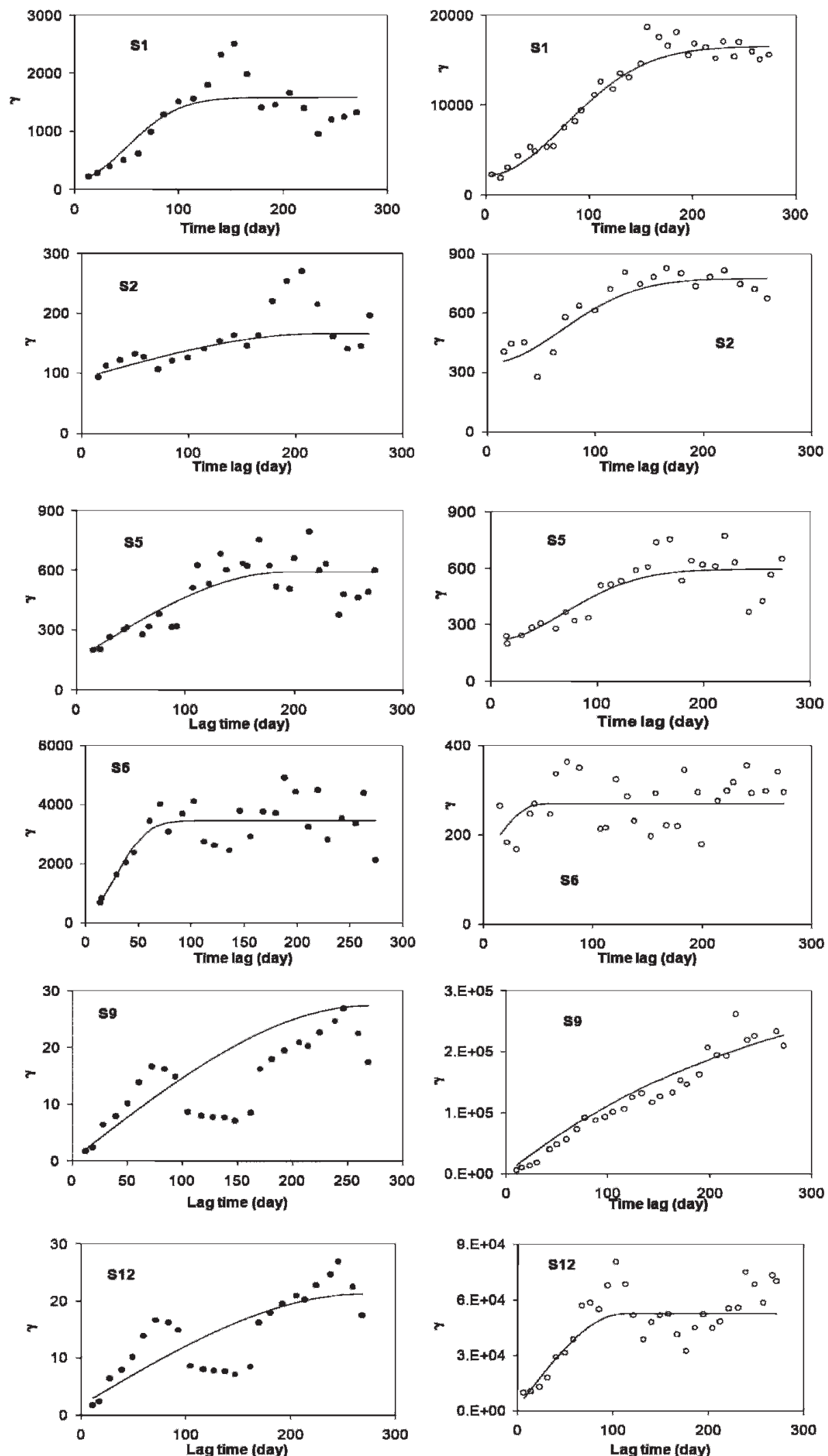

Figure 4. Non-periodic variogarams of discharge (right panel) and EC (left panel) values. 
Table 7. The value of fitting criteria in modeling of non-periodic variograms (the best models are presented by bold numbers).

\begin{tabular}{|c|c|c|c|c|c|c|}
\hline \multirow[b]{2}{*}{ Spring } & \multirow[b]{2}{*}{ Fitting Criteria } & \multicolumn{5}{|c|}{ Model } \\
\hline & & Exp. & Gau. & Sph. & Dub. Sph. & Dub. Exp. \\
\hline \multicolumn{7}{|l|}{ Gilan } \\
\hline \multirow{3}{*}{ Discharge } & RMSE & 1742 & 1177 & 1330 & 1255 & 1761 \\
\hline & AIC & 575 & 551 & 558 & 558 & 580 \\
\hline & SSE & 9.8 & 5 & 6.3 & 6.9 & 12.7 \\
\hline \multirow[t]{3}{*}{ Elec. Cond. } & RMSE & 422 & 357 & 373 & 696 & 510 \\
\hline & AIC & 324 & 317 & 319 & 349 & 336 \\
\hline & SSE & 79 & 35 & 34 & 34 & 69.5 \\
\hline \multicolumn{7}{|l|}{ Golin } \\
\hline \multirow{3}{*}{ Discharge } & RMSE & 85 & 68 & 71 & 128 & 94 \\
\hline & AIC & 243 & 234 & 236 & 264 & 252 \\
\hline & SSE & 9.5 & 6.8 & 8 & 20 & 10 \\
\hline \multirow[t]{3}{*}{ Elec. Cond. } & RMSE & 38.7 & 32.7 & 37.1 & 34.4 & 39.3 \\
\hline & AIC & 223 & 216 & 222 & 222 & 228 \\
\hline & SSE & 5.1 & 7.1 & 4.7 & 6.8 & 13.4 \\
\hline \multicolumn{7}{|l|}{ Piran } \\
\hline \multirow{3}{*}{ Discharge } & RMSE & 99.4 & 90.4 & 91 & 145 & 112 \\
\hline & AIC & 330 & 325 & 325 & 353 & 395 \\
\hline & SSE & 16 & 13 & 14 & 53 & 21 \\
\hline \multirow[t]{3}{*}{ Elec. Cond. } & RMSE & 103 & 93.6 & 94 & 96 & 124.3 \\
\hline & AIC & 386 & 380 & 381 & 386 & 345 \\
\hline & SSE & 25.4 & 20 & 18.5 & 19.5 & 7.3 \\
\hline \multicolumn{7}{|l|}{ Gharabolagh } \\
\hline \multirow[t]{3}{*}{ Discharge } & RMSE & 59 & 62 & 59 & 96 & 81 \\
\hline & AIC & 353 & 356 & 353 & 386 & 376 \\
\hline & SSE & 17 & 18 & 17 & 40 & 30 \\
\hline \multirow[t]{3}{*}{ Elec. Cond. } & RMSE & 684 & 659 & 661 & 1023 & 851 \\
\hline & AIC & 430 & 428 & 428 & 455 & 445 \\
\hline & SSE & 11 & 9.2 & 9.3 & 27 & 16 \\
\hline \multicolumn{7}{|l|}{ Berghan } \\
\hline \multirow[t]{3}{*}{ Discharge } & RMSE & 58,067 & 73,290 & 60,766 & 69,655 & 24,986 \\
\hline & AIC & 766 & 780 & 769 & 781 & 719 \\
\hline & SSE & 741 & 7613 & 856 & 503 & 182 \\
\hline \multirow[t]{3}{*}{ Elec. Cond. } & RMSE & 4.9 & 4.8 & 4.5 & 4.4 & 6.5 \\
\hline & AIC & 166 & 165 & 162 & 164 & 184 \\
\hline & SSE & 70 & 75 & 67 & 64 & 125 \\
\hline \multicolumn{7}{|l|}{ Atashgah } \\
\hline \multirow[t]{3}{*}{ Discharge } & RMSE & 13,574 & 11,244 & 11,733 & 20,497 & 13,894 \\
\hline & AIC & 820.2 & 806.6 & 693.4 & 732 & 707.9 \\
\hline & SSE & 181.1 & 97.8 & 116.2 & 318 & 194 \\
\hline \multirow[t]{3}{*}{ Elec. Cond. } & RMSE & 13.8 & 16.57 & 4.6 & 25.4 & 14 \\
\hline & AIC & 275.5 & 286.5 & 163.1 & 262.9 & 281.8 \\
\hline & SSE & 42.5 & 46.3 & 70.65 & 145.4 & 47.9 \\
\hline
\end{tabular}

Concentrated rapid recharge through the sinkholes is the dominant recharge mechanism for Sheshpir Spring (S8).

Group 2 includes Sarabgarm (S3), Rijab (S7), Tangkelagari (S11) and Enakak (S14) Springs that are character- ized by (1) a positive correlation between discharge and EC values (Fig. 2); and (2) periodic structures in the variograms but with different temporal behaviors between discharge and EC (Fig. 3). This group may belong to 

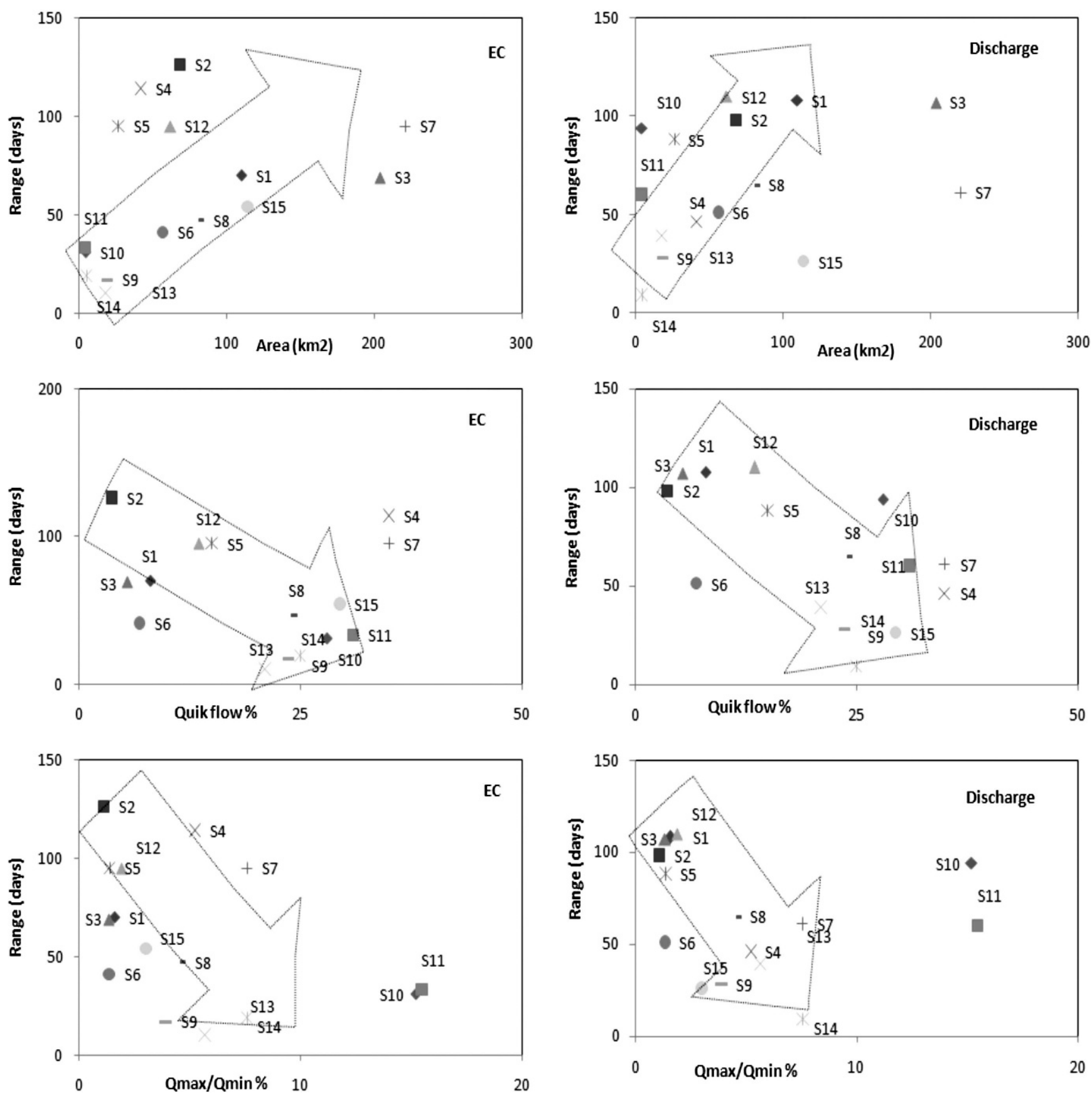

Figure 5. Relationship between residence-time range (A1) and selected characteristics of the springs.

a karst system or subsystem that is poorly developed and is dominantly displaced by a piston-flow regime. Previous findings about Enakak Spring (S14) (Keshavarz, 2003) confirm our interpretation of a karst system or subsystem dominated by a piston-flow regime for Group 2.

Group 3 includes Gilan Spring (S1), Marab Spring (S4), Morikosh Spring (S10), Atashgah Spring (S12), Shosh Spring (S13) and Ghomp Spring (S15), which are subjected to (1) a negative correlation between discharge and EC values (Fig. 2); and (2) different temporal structure in variograms of discharge and EC (Figs. 3 and 4). We believe this group is supported by a well-developed karst system or subsystem that provides higher discharge values that coincide with lower values of EC. Quick response of the karst system or susbsystem to precipitation events causes different temporal behaviors in variograms of discharge and $\mathrm{EC}$. 
Table 8. The ratio of difference between obtained ranges based of variograms of discharge $\left(R_{Q}\right)$ and electrical conductivity $\left(R_{E C}\right)$.

\begin{tabular}{|c|c|c|c|c|c|c|}
\hline \multirow[b]{2}{*}{ Spring } & \multicolumn{2}{|c|}{ Residence Time (d) } & \multirow[b]{2}{*}{$\left|R_{E C}-R_{Q}\right|$} & \multirow{2}{*}{$\frac{\left|R_{E C}-R_{Q}\right|}{\left[\left(R_{E C}+R_{Q}\right) / 2\right]}$} & \multirow[b]{2}{*}{$\times 100$} & \multirow[b]{2}{*}{ Group } \\
\hline & $\begin{array}{c}\text { Elec. Cond. } \\
\left(R_{E C}\right)\end{array}$ & $\begin{array}{l}\text { Discharge } \\
\quad\left(R_{Q}\right)\end{array}$ & & & & \\
\hline Gilan & 70 & 108 & 38 & 43 & & 3 \\
\hline Golin & 126 & 98 & 28 & 25 & & 1 \\
\hline Sarabgarm & 69 & 107 & 38 & 43 & & 2 \\
\hline Marab & 114 & 46 & 68 & 85 & & 3 \\
\hline Piran & 95 & 88 & 7 & 8 & & 1 \\
\hline Gharabolagh & 41 & 51 & 10 & 22 & & 1 \\
\hline Rijab & 95 & 61 & 34 & 44 & & 2 \\
\hline Sheshpir & 47 & 65 & 18 & 32 & & 1 \\
\hline Berghan & 17 & 28 & 9 & 49 & & 1 \\
\hline Morikosh & 31 & 94 & 63 & 100 & & 3 \\
\hline Tangkelagari & 33 & 60 & 27 & 58 & & 2 \\
\hline Atashgah & 268 & 110 & 158 & 84 & & 3 \\
\hline Shosh & 10 & 39 & 29 & 118 & & 3 \\
\hline Enakak & 19 & 9 & 10 & 71 & & 2 \\
\hline Ghomp & 54 & 26 & 28 & 70 & & 3 \\
\hline
\end{tabular}

Note: $E C$ is electrical conductivity.

$Q$ is discharge.

\section{Conclusions}

The time series that describe discharge and EC variations at the springs represent aquifer behavior over the time domain. The application of variogram analysis suggests two temporal behaviors characterize the time series of discharge and EC at springs. These temporal behaviors include periodicity and nugget effect plus one or two temporal structures. For the springs studied here, the periodicity ranges from 100 to 316 days and from 82 to 300 days for variogram of discharge and $\mathrm{EC}$, respectively. The temporal structure in one cyclical period is explored by application of variogram on partial data in a cycle.

Some of the variograms are modeled by double exponential or spherical models which introduce two temporal ranges (i.e., A1 and A2). The short range (A1) can be considered as an indication of water residence time in well-developed karst conduits, while the entire karst system is responsive to the long range (A2). The springs are classified into three groups according to differences between ranges obtained by variograms of discharge and EC that belong to the development of karst in each system. The results obtained in this study confirm previous findings of the study area and provide valuable new findings regarding the temporal structure of the aquifers and additional insights into the karst systems. This research also illustrates how variogram analysis can improve our understanding of karst systems by using time series of physico-chemical parameters. The authors propose the application of variogram analysis on time series of physicochemical parameters as a part of karst spring studies.

\section{ACKNOWLEDGEMENTS}

The authors would like to thank Dr. Arthur N. Palmer of the Earth Science Department of the State University of New York and Dr. Thomas Johnson of the National Center for Environmental Assessment of the U.S. Environmental Protection Agency for their review and constructive criticisms of the manuscript. The authors thank Professor E. Raeisi of the Earth Science Department of the Shiraz University of Iran for providing all data. The first author would like to thank the Research Council of Shiraz University for financial support.

\section{REFERENCES}

Alavi, M., 2004, Regional stratigraphy of the Zagros fold-thrust belt of Iran and its proforeland evaluation: American Journal of Science, v. 304, p. $1-20$.

Alavi, M., 2007, Structures of the Zagros fold thrust belt in Iran: American Journal of Science, v. 307, p. 1064-1095.

Bacchi, B., and Kottegoda, N.T., 1995, Identification and calibration of spatial correlation patterns of rainfall: Journal of Hydrology, v. 165, p. 311-348.

Bakalowicz, M., 2005, Karst groundwater: A challenge for new resources: Hydrogeology Journal, v. 13, p. 148-160.

Berne, A., Delrieu, G., Creutin, J.D., and Obled, C., 2004, Temporal and spatial resolution of precipitation fall measurements required for urban hydrology: Journal of Hydrology, v. 299, p. 166-179.

Buytaert, W., Celleri, R., Willems, P., Bievre, B.D., and Wyseure, G., 2006, Spatial and temporal precipitationfall variability in mountain- 
ous areas: A case study from the south Ecuadorian Andes: Journal of Hydrology, v. 329, p. 413-421.

Chambers, J.M., Cleveland, W.S., Kleiner, B., and Tukey, P.A., 1983, Graphical methods for data analysis: Murray Hill, N.J., Bell Telephone Laboratories Inc., 395 p.

Desmarais, K., and Rojstaczer, S., 2002, Inferring source waters from measurements of carbonate spring response to storms: Journal of Hydrology, v. 260, p. 118-134.

Deutsch, C.V., and Journel, A.G., 1992, GSLIB: Geostatistical software library and user's guide: New York, Oxford University Press, $340 \mathrm{p}$.

Farnham, I.M., Stetzenbach, K.J., Singh, A.K., and Johannesson, K.H., 2000, Deciphering groundwater flow system in Oasis Valley, Nevada, using tracer element chemistry, multivariate statistics and geographical information systems: Mathematical Geology, v. 32, no. 8, p. $943-968$.

Ford, D.C., and Williams, P.W., 2007, Karst hydrogeology and geomorphology, Chichester: West Susex, UK, John Wiley \& Sons, Ltd, $562 \mathrm{p}$.

Gillieson, D., 1996, Caves: Processes, development, and management: Cambridge, Mass., Blackwell Publishers, Inc., 324 p.

Goovaerts, P., 1997, Geostatistics for natural resources evaluation: New York, Oxford University Press, $483 \mathrm{p}$

Goovaerts, P., Sonnet, P., and Navarre, A., 1993, Factorial kriging analysis of springwater contents in the Dyle River basin, Belgium: Water Resources Research, v. 29, no. 7, p. 2115-2125.

Hess, J.W., and White, W.B., 1988, Storm response of the karstic carbonate aquifer of south central Kentucky: Journal of Hydrology, v. 99 , no. $3-4$, p. $235-252$.

Holawe, F., and Dutter, R., 1999, Geostatistical study of precipitation series in Austria: Time and space: Journal of Hydrology, v. 219, p. $70-82$.

Isaaks, E.H., and Srivastava, R.M., 1989, An introduction to applied geostatistics: New York, Oxford University Press, 561 p.

James, G.A., and Wynd, J.G., 1965, Stratigraphic nomenclature of Iranian Oil Consortium Agreement area: Bulletin of American Association of Petroleum Geologists, v. 49, no. 12, p. 2182-2245.

Karimi, H., 2003, Hydrogeological behaviour of the Alvand basin karst aquifers, Kermanshah [Ph.D. dissertation]: Shiraz, Iran, Shiraz University, $212 \mathrm{p}$.

Karimi, H., Raeisi, E., and Zare, M., 2005a, Physicochemical time series of karst springs as a tool to differentiate the source of spring water: Carbonate and Evaporates, v. 20, no. 2, p. 138-147.

Karimi, H., Raeisi, E., and Bakalowicz, M., 2005b, Characterizing the main karst aquifers of the Alvand basin, northwest of Zagros, Iran, by a hydrogeochemical approach: Hydrogeology Journal, v. 13, p. 787-799.

Keshavarz, T., 2003, Study on the karstic artesian aquifers in the Khersan3 Dam site [M.Sc. Thesis]: Shiraz, Iran, Shiraz University, $212 \mathrm{p}$.

Kitanidis, P.K., 1997, Introduction to geostatistics: Application to hydrogeology: Cambridge University Press, UK, 249 p.

Kolovos, A., Christakos, G., Hristopulos, D.T., and Serre, M.L., 2004, Methods for generating non-separable spatiotemporal covariance models with potential environmental applications: Advances in Water Resources, v. 27, p. 815-830.

Kovacs, A., Perrochet, P., Kiraly, L., and Jeannin, P.Y., 2005, A quantitative method for the characterisation of karst aquifers based on spring hydrograph analysis: Journal of Hydrology, v. 303, p. $152-164$

KWPA, 2009, Khuzestan Water and Power Authority, http://www.kwpa. ir/ [accessed June 22, 2009].

Kyriakidis, P.C., Miller, N.L., and Kim, J., 2004, A spatial time series framework for simulating daily precipitation at regional scales: Journal of Hydrology, v. 297, p. 236-255.

Larocque, M., Mangin, A., Razack, M., and Banton, O., 1998, Contribution of correlation and spectral analysis to the regional study of a large karst aquifer (Charente, France): Journal of Hydrology, v. 205, p. 217-231.

Lopez-Chicano, M., Bouamama, M., Vallejos, A., and Pulido-Bosch, A., 2001, Factors which determine the hydrogeochemical behavior of karstic springs: A case study from the Betic Cordilleras, Spain: Applied Geochemistry, v. 16, p. 1179-1192.

Manga, M., 1999, On the timescales characterizing groundwater discharge at springs: Journal of Hydrology, v. 219, p. 56-69.

Mangin, A., 1984, Pour une meilleure connaissance des systems hydrologiques a partir des analyses correlatoire at spectrale: Journal of Hydrology, v. 67, p. 25-43.

Mangin, A., 1994, Karst hydrogeology, in Gilbert, J., Danielopol, D.L., and Stanford, J.A., eds., Groundwater ecology: San Diego, Academic Press, p. 43-67.

Milanović, P.T., 1981, Karst hydrogeology, Colorado, Water Resources Publications, $434 \mathrm{p}$.

Minasny, B., McBratney, A.B., and Whelan, B.M., 2005. VESPER version 1.62. Australian Centre for Precision Agriculture, McMillan Building A05, The University of Sydney, NSW 2006, (http://www. usyd.edu.au/su/agric/acpa).

Mohammadi, Z., and Raeisi, E., 2007, Hydrogeological uncertainties in delineation of leakage at karst dam sites, the Zagros Region, Iran: Journal of Cave and Karst Studies, v. 69, no. 3, p. $305-317$.

Mohammadi, Z., Raeisi, E., and Bakalowicz, M., 2007, Evidence of karst from behavior of the Asmari limestone aquifer at the Khersan3 dam site, Southern Iran: Hydrological Science Journal, v. 52, no. 1, p. 206-220.

Moore, G.K., 1992, Hydrograph analysis in fractured rock terrane: Ground Water, v. 30, no. 3, p. 390-395.

Padilla, A., and Pulido-Bosch, A., 1995, Study of hydrographs of karstic aquifers by means of correlation and cross-spectral analysis: Journal of Hydrology, v. 168, p. 73-89.

Palmer, A.N., 2007, Cave geology: Dayton, Ohio, Cave Books, 454 p.

Panagopoulos, G., and Lambrakis, N., 2006, The contribution of time series analysis to the study of the hydrodynamic characteristics of the karst aquifers of Greece (Trifilia, Almyros Crete): Journal of Hydrology, v. 329, p. 368-376.

Pezeshpoor, P., 1991, Hydrogeological and hydrochemical evaluation of Kuh-e Gar and Barm Firooz Springs, [M.Sc. thesis]: Shiraz, Shiraz University, $282 \mathrm{p}$.

Raeisi, E., 2004, Iran cave and karst, in Gunn, J., ed., Encyclopedia of Cave and Karst: New York, Fitzroy Dearborn, p. 460-461.

Raeisi, E., and Laumanns, M., 2003, Cave directory of Iran: Berlin, Berliner Hohlenkundliche Berichte, $101 \mathrm{p}$.

Raeisi, E., and Karami, G., 1997, Hydrochemographs of Berghan karst spring (S9) as indicators of aquifer characteristics: Journal of Cave and Karst Studies, v. 59 , no. 3, p. 112-118.

Rouhani, S., and Wackernagel, H., 1990, Multivariate geostatistical approach to space-time data analysis: Water Resources Research, v. 26 , no. 4 , p. $585-591$.

Scanlon, B.R., and Thrailkill, J., 1987, Chemical similarities among physically distinct spring types in a karst terrain: Journal of Hydrology, v. 89, p. 259-279.

Silliman, S.E., Boukari, M., Crane, P., Azonsi, F., and Neal, C.R., 2007, Observation on elemental concentrations of groundwater in central Benin: Journal of Hydrology, v. 335, p. 374-388.

StatSoft, Inc., 2001, Statistica for Windows, Release 6, Tulsa, Oklahama.

Stocklin, J., and Setudehnia, A., 1977, Stratigraphic lexicon of Iran, Report No. 18-1971: Tehran, Iran, Geological Survey of Iran, $376 \mathrm{p}$.

Webster, R., and Oliver, M., 2001, Geostatistics for environmental scientists, Chichester: West Sussex, UK, John Wiley and Sons, Ltd, $271 \mathrm{p}$.

White, W.B., 1988, Geomorphology and hydrology of karst terrains: Oxford, Oxford University Press, 464 p. 